oxtremely high frequency electromagnetic waves (below $1 \mathrm{~mm})$; $£ 2,630$ to Dr. B. V. Bowden, principsl of the Manchester Colloge of Science and Tochnology, for the continuation of work on the developmont of narrow pass band dye filtors (for night sky astronomical photography);

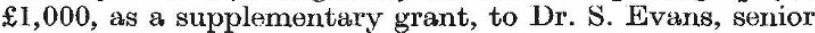
assistant in polar researeh, University of Cambridg(), for the devolopmont of an instrument for measuring the dopth of continontal ice sheets by a radar technique; $£ 1,870$ to Dr. E. T. Hall, diroctor of the resoarch laboratory for archæology and the history of art, University of Oxford, for the development $(a)$ of a fully transistorized differential flux-gato magnotometer, and $(b)$ of a miniaturized flux-gato compass; $£ 725$, as a supplementary grant, to Dr. D. W. Hill, senior lecturer in physies, Research Dopartmont of Anæsthoties, Royal College of Surgeons of England, for the construction of an infra-red gas or vapour analysor using interforence filters; $£ 5,250$ to Dr. J. V. P. Long, assistant diroctor of rosoarch in tho Department of Mineralogy and Petrology, University of Cambridge, for the development of an ion-probe analyser for mass spoctrometric measurements on selected microvolumes of $1-20 \mu$ diameter in polishod specimens of minerals and motals; $£ 5,690$ to Prof. J. Ring, Department of Applied Physics, University of Hull, for the construction of apparatus for research into the applications of Moiré fringes as analogue Fourior transformers; $£ 2,300$ to Dr. T. H. Wilmshurst, Departmont of Eloctronics, University of Southampton, for the construction of an electron spin resonance spectromoter for examining shortlived paramagnetic species produced by a pulsed light source.

The Paul Instrument Fund Committoo, composod of representatives of the Royal Society, the Institute of Physics and the Physical Society and tho Institution of Electrical Engineers, was set up in 1945 "to receive applications from British subjocts who are resoarch workers in Creat Britain for grants for the design, construction and maintenance of novel, unusual or much improved types of physical instruments and apparatus for investigations in pure or applied physical science".

\section{The Indian Botanical Society: Awards}

To commemorate the sixtieth birthday of Prof. P. Maheshwari, University of Delhi, tho Indian Botanical Society presented him with an advance copy of the Maheshwari Commemoration Volume in recognition of his work of exeeptional merit for the advancement of botanical research in India. The Volume is a compilation of articles contributed by eminent botanists from all over the worid and represents almost all disciplines of botany. It is expected that it will be published in a month or so.

The Society awarded the Birbal Sahni Medal for 1962 to Prof. T. S. Sadasivan, Madras University, for organizing, promoting and fostering botanical studies in India. Prof. Sadasivan is the sixth recipient of this award.

\section{University News:}

London

The following titles have been conferred: Professor, Dr. J. M. Alexander (enginesring plastieity), in respect of his post at the Imporial College of Science and Technology; Dr. T. Barnard (micropalieontology), in respect of bis post at University Colloge; Dr. F. R. Boll (exporimontal veterinary modicine), in respect of his post at the Royal Veterinary College; Dr. L. P. Mair (applied anthropology), in respoct of her post at the London School of Economies; Dr. M. J. Soaton (physics), in respect of his post at University Colloge. Reader, Dr. D. F. Barton (statisties), in respoet of his post at Univorsity Collogo; Mr. H. Billett (mochanical engineering), in respect of his post at University College; Dr. W. G. Chalonor (botany), in respect of his post at University Collego; Dr. R. W. Guillery (anatomy), in respect of his post at University College; Dr. K. J. Ivos (civil and munioipal onginooring), in respect of his post at University Colloge; Dr. V. H. T. James (chemical endocrinology), in respect of his post at St. Mary's Hospital Medieal Sehool; Dr. C. R. Boddington Joyco (psycho-pharmacology), in respect of his post at tho London Hospital Medical Collogo; Mr. O. C. J. Lippold (physiology), in respect of his post at University Colloge; Dr. D. H. Martin (physies), in respect of his post at Quoon Mary College; Dr. I). V. W. Parke (biochomistry), in respect of his post at St. Mary's Hospital Medical School; Dr. A. F. Seager (mineralogy), in respect of his post at Birkbeck College; Dr. D. A. Walker (botany), in respect of his post at Queon Mary College. The following appointments to readerships have been mado: Dr. E. M. Deuchar (ombryology), tonablo at Univorsity College; Dr. B. R. Rabin (biochemistry), tenable at Univorsity College; Dr. C. W. Rees (organic chomistry), tenable at King's Colloge.

\section{Announcements}

Miss Racher Carson, author and ocologist, and Prof. H. Clifford Darby, professor of goography in Univorsity College, London, have been awardod tho Cullum Geographical Modal and the Charles P. Daly Medal, respectively, by the American Goographical Society for thoir respective contributions in the fields of conservation and goography. Miss Carson, who is well known for her books, Silent Spring and The Sea Around Us, has been affiliated with tho Marine Biological Laboratory, Woods Hole, Mass., since 1929. Prof. Darby is known most widely for his work in historical geography, particularly for his book, The Domesday Geography of England, of which four volumes have so far been published; earlier this yoar he was awarded tho Patron's Medal of the Royal Geographical Socioty. He was president of the British Institute of Geographers in 1961.

AT the tenth general assembly of the International Council of Sciontifie Unions held recently in Vienna, Dr. H. W. Thompson, of St. John's Colloge, Oxford, and university reader in infra-red spectroscopy, was elected prosident of the Couneil for the next two years. Prof. D. Blaskovic, vice-chairman of the Czechoslovak Academy of Sciences and director of the Academy's Virological Institute, was elected secretary-general, and Ing. Gen. G. Laclavère, National Geographic Institute, France, was elected treasurer.

THe Memoirs and Proceedings, 1962-63, of the Manchester Literary and Philosophical Society (105. Pp. $128+$ xlix. Manchester: Manchester Literary and Philosophical Society, 1963. 31s. 6d.) contain M. W. Thring's Joule Memorial Lecture, "Can Machines make Humans Happier ?", and papers by E. Mendoza on the history of the kinetic theory of gases; by F. C. Toy on universitios, rosearch associations and industry; and by $\mathrm{S}$. Toulmin on the discovery of timo. The volume also includes the annual report of the Council, and lists of spocial loctures, membors and mombors of Council.

THE twolfth inter-university goological congress entitled "The Present is the Key to the Past" will be held in tho University of Shoffield during Decombor 15-18. Further information can be obtained from $H$. G. Davies, Dopartmont of Geology, University of Shoffiold, Mappin Streot, Shoffiold, 1.

A symposium on "The Use of Redundancy in System Design", arranged by the Systoms Enginoering Section of the Society of Instrument Technology, will be held at the Northampton College of Advanced Teehnology on Fobruary 14. Topies under diseussion will include: automatic landing of aircraft; nuclear power systems; techniques of redundancy in logical circuits; reversionary modes in complex systems. Further information can be obtained from the Symposium Secretary, Society of Instrument Technology, 20 Peol Street, London, W.8. 